\title{
Retinoblastoma Pathologic Distant Metastasis TNM Finding v7
}

National Cancer Institute

\section{Source}

National Cancer Institute. Retinoblastoma Pathologic Distant Metastasis TNM Finding v7. NCI Thesaurus. Code C88743.

A pathologic finding about one or more characteristics of retinoblastoma, following the rules of the TNM AJCC V7 classification system as they pertain to distant metastases. There is no pathologic MO for retinoblastoma. (from AJCC 7th Ed.) 